\title{
4 Effect of the COVID-19 pandemic on selected economies in Eastern Europe
}

\author{
Olesia Chornenka, Oleksij Kelebaj, \\ Monika Bolinska, Pawet Dykas, and \\ Rafat Wista
}

\subsection{Introduction}

The depth of fall in aggregate flow values (gross domestic product (GDP), investment, exports) in Q2 of 2020 in all analyzed economies of the EU was unprecedented in the post-war history of the current member states of the European Union. The pandemic also had an adverse effect on other developed economies of the world (World Bank, 2020). The 2020+ pandemic posed a much more serious challenge for the countries located in Eastern Europe. The most severe effects of the 2020+ pandemic were reported in the tourist and transport sectors and in the healthcare system. Initial assessments of the economic and social impact of the COVID-19 pandemic on the countries located in Eastern Europe were carried out already in 2020 among others by: Kulyts'kyy (2020a, 2020b), Drobot, Makarov, Nazarenko and Manasyan (2020), Zhalilo, Bazylyuk, Kovalivs'ka and Kolomiyets' (2020) or the World Bank (2020).

Kulyts'kyy (2020a) assessed the effect of the pandemic on the Ukrainian economy, by analyzing existing and forecast fluctuations in basic macroeconomic indicators in a short- and a long-time horizon in the context of general instability of the global economy caused by the 2020+ pandemic. He additionally (2020b) analyzed the impact of the 2020+ pandemic on the Ukrainian labor market. He observed the most severe short-term effect of the pandemic in the Ukrainian service sector.

The World Bank (2020) in its description of macroeconomic effects of the pandemic on Russia indicates a massive drop in economic activity in Q2 of 2020. Surveys conducted by the World Bank demonstrate that the crisis caused by the coronavirus pandemic severely affected small and medium-sized enterprises (SMEs) that are more sensitive to supply and demand shocks than larger companies. The 2020+ pandemic has deepened the economic crisis in Russia, caused among other factors by dramatic falls in prices for petroleum. The average price for Russian Urals oil brand was USD 41.73 per barrel in 2020. The value amounted in 2019 to USD 63.59, 
i.e. it was $34 \%$ lower on average in 2020 , exerting an adverse effect on both the state budget and trade balance.

Drobot, Makarov, Nazarenko and Manasyan (2020) assessed the effect of coronavirus spread on the condition of selected Russian industries. Their research demonstrates that, in the context of general adverse effects of the $2020+$ pandemic on the Russian economy, selected industries reported growths in sales - of foodstuffs, chemicals, pharmaceuticals and medical instruments and equipment. Drobot, Makarov, Nazarenko and Manasyan (2020) construct two scenarios of overcoming the crisis of the Russian economy. Under an optimistic scenario (assuming a substantial rise in oil prices), Russia will reach the pre-crisis level of 2019 by mid-2021. Under a pessimistic scenario, the crisis in Russia caused by the pandemic and fall in prices for fossil fuels will not be overcome until 2023.

Zhalilo, Bazylyuk, Kovalivs'ka and Kolomiyets' (2020) carried out an indepth analysis of the impact of the 2020+ pandemic on the Ukrainian economy, adopting macroeconomic, sectoral, social and spatial perspectives. The authors emphasize that the final containment of the COVID-19 virus spread will not mark the end of the recession in Ukraine. They observed a particularly strong effect of the $2020+$ pandemic on the condition of unstable national economic systems. The effect of the coronavirus spread on an institutionally unstable economic system was also analyzed by the National Bank of Ukraine (2020). Attention was directed to an increased risk of short- and long-term internal (inflation) and external (strongly negative balance of payments) instability.

That synthetic review of pandemic effects on social and economic life demonstrates a varying impact of the 2020 health issue on relatively immature social and economic systems. As we focus in this book on European economies, and a sufficient set of statistical data (quarter-over-quarter) on institutionally unstable economic systems is not available, we limit our analysis and assessment of the effects of the 2020+ pandemic to two countries located in Eastern Europe.

This chapter aims to analyze and assess the impact of the COVID-19 pandemic on the economies of Russia and Ukraine in comparison to EU economies. The first section of this chapter contains an analysis of the GDP (per capita) index. The analysis covers a long (2006-2020) and a short period (Q2 of 2019 vs. Q2 of 2020). The second section of this chapter discusses spatial interactions between the European Union, the Russian Federation and Ukraine taking place in labor and product markets. The third section describes selected forms of fiscal intervention used by the governments of Ukraine and Russia in 2020. This chapter supplements the macro-analyses conducted in Chapter 2 by describing two countries from outside the European Union, but also builds a connection with Chapter 3 that discusses fiscal interventions in the EU member states. 


\subsection{Changes in GDP of Ukraine and Russia vs. the EU economy}

The 1990s saw a deep economic recession in Ukraine. GDP per capita (at purchasing power parity (PPP), and fixed prices from 2017) fell from USD 15,700 in 1990 to USD 6,700 in 1999. By 2019, it had not yet returned to its 1990 level (World Bank, 2021). The situation in Ukraine was indirectly worsened by the Russian financial crisis of 1998. The social and economic situation in the first decade of Ukrainian independence was influenced not only by a revolutionary shock but also by a complete absence of market economy institutions.

The scenario of economic development in the last decade of the 20th century was almost the same in Russia and in Ukraine. A difference lay in the levels and not in the depth of the recession. Russian GDP per capita (at PPP, and fixed prices from 2017) fell from USD 21,500 in 1990 to USD 13,200 in 1999. But by 2019 it had reached USD 27,000 per capita (World Bank, 2021). Against that background, the economies of European Communities and then the European Union can be described as a space of stable economic growth. GDP per capita in the European Union (at PPP, and fixed prices from 2017) in 1990 amounted to USD 28,600 and after 30 years to USD 44,400 per capita.

Ukrainian real GDP per capita grew in 2000-2008 by almost $100 \%$. The Russian financial crisis combined with the gas disputes with Russia led to a deep recession in Ukraine in 2009 (a fall by almost 15\%), followed by the return of the Ukrainian economy in 2011/2012 to the growth path that continued until 2014. The accumulated real growth in GDP per capita amounted to $11.2 \%$ in that period. The growth trend discontinued after the Euromaidan movement (2013-2014), the annexation of Crimea by Russia, and fighting with pro-Russian separatists in eastern Ukraine. Ukrainian real GDP per capita fell in 2014-2015 by almost 10\%. In 2020, Ukrainian GDP per capita was similar to small post-Soviet states such as Moldova, Georgia or Armenia.

Like in the 1990s, the curve of Russian economic development took on a similar shape to Ukraine in the first two decades of the 21st century. However, the levels are significantly higher. Considering the institutional aspect, Russia is capable of using resources and solutions that are unavailable in Ukraine. These include for example Russia's participation in a regional integration group (the Eurasian Customs Union) and its political stability (considerable power resting with the president).

Figures 4.1 (a), (b) and (c) offer a slightly different perspective on fluctuations in GDP per capita in Ukraine, Russia and the European Union (at PPP, and fixed prices from Q2 of 2020) in the years 2006-2020 quarter-overquarter. The economic history of Ukraine, Russia and the European Union as a whole over the last 30 years provides evidence of diversified levels of institutional, political and economic stability in those three economic areas. 


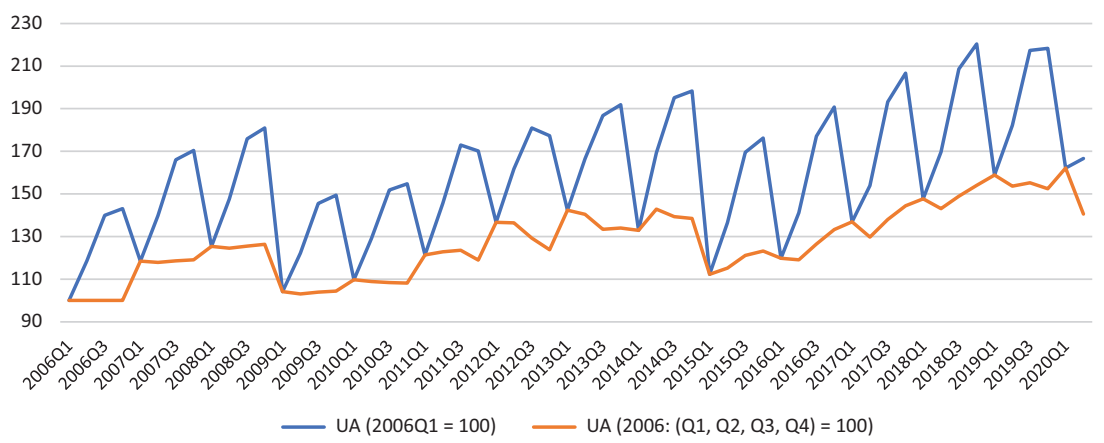

Figure 4.1a Changes in Gross Domestic Product per capita, at PPP, quarter-overquarter $(2006-2020,2020=100)$ in (a) Ukraine. Source: own calculation based on http://www.ukrstat.gov.ua/ (accessed: 2021-01-30).

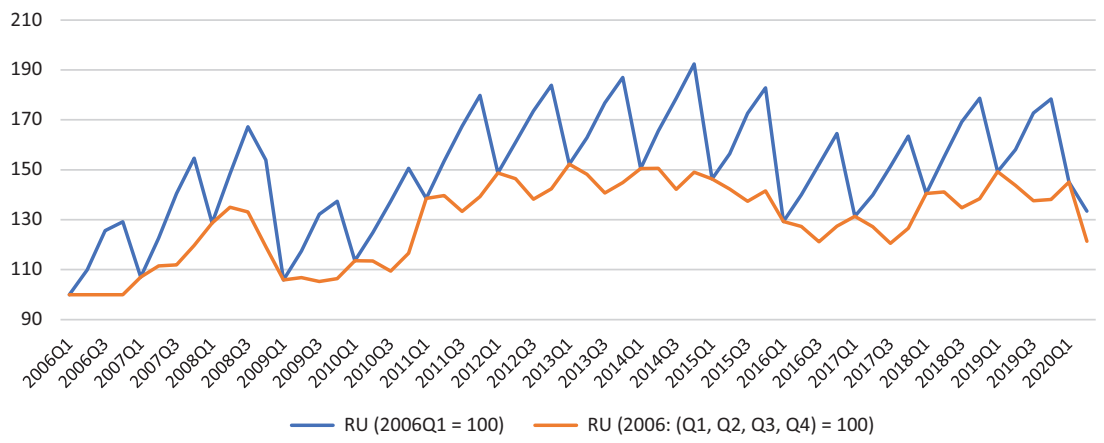

Figure 4.1b Changes in Gross Domestic Product per capita, at PPP, quarter-overquarter $(2006-2020,2020=100)$ in (b) Russia. Source: own calculation based on https://eng.rosstat.gov.ru (accessed: 2021-01-30).

The same exogenous shocks produce similar short-term effects (and this is not surprising under the conditions of globalization), but their long-term consequences vary in form and time. The first decade of the 21 st century in Ukraine saw economic growth following a decade of deep revolutionary recession in the 1990s. The growth wave in this phase of the economic cycle was abruptly discontinued in Q1 of 2009, due to an exogenous shock that firstly affected the United States in 2008 and then spread across the global economy. As a result, the Ukrainian economy slipped into a three-year recession. The years 2012-2014 saw a return to the growth path characteristic of the era preceding the 2008+ crisis. A series of protests in Ukraine provoked by Ukraine's decision to put off signing the association agreement with the 


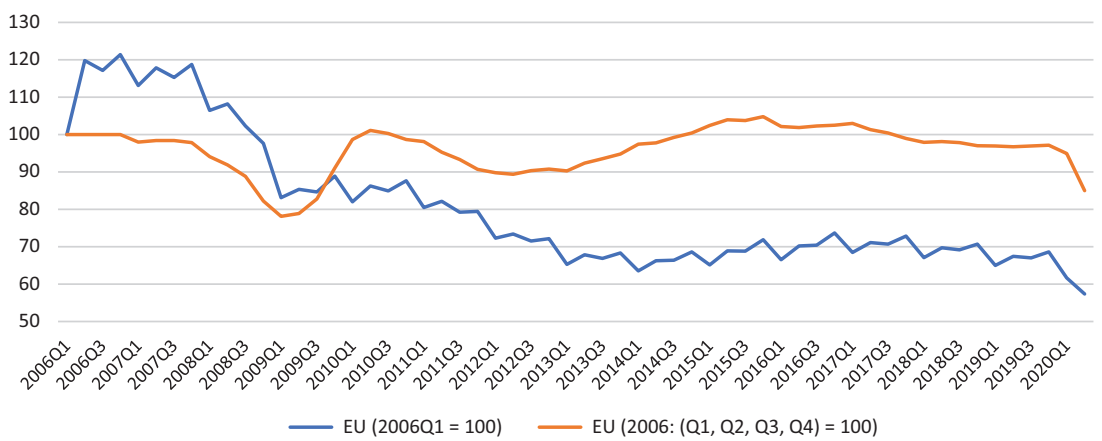

Figure 4.1c Changes in Gross Domestic Product per capita, at PPP, quarter-overquarter $(2006-2020,2020=100)$ in $(c)$ the European Union. Source: own calculation based on https://ec.europa.eu/eurostat/data/database (accessed: 2021-01-30).

European Union (beginning in November 2013), followed by demonstrations in many towns of eastern and southern Ukraine, including Donetsk, Luhansk, Kharkiv and Odessa, and growing separatist trends in Crimea, resulted in a repeated sudden reversal of growth trends in the Ukrainian economy. This time, it was a short-term recession.

The years 2015-2019 saw spectacular growth, followed by another dramatic and deep downturn caused by the global pandemic. Hence, the Ukrainian economy experienced three major demand and supply shocks. The Russian economy recorded a fall of $7.8 \%$ in 2009 , when the oil prices dropped to the level of USD 40-50 per barrel. At that time of crisis, Russia possessed considerable foreign exchange reserves amassed in the years 2000-2008 due to high and rising prices for raw materials, including especially petroleum (2008/2009: about USD 140 per barrel).

The year 2009 marked the end of the longest era of uninterrupted dynamic economic growth in modern Russia, lasting from 2000 and reaching about $7 \%$ annually on average. Despite unfavorable macroeconomic and microeconomic indicators, Russians' real income continued to grow during the 2008+ crisis, due to considerable funds from foreign exchange reserves redirected to the domestic market (Lobuszewska, Kazimierska \& Mańkowski, 2015: 20).

When the Russian financial market was affected by a crisis in midDecember 2014, the authorities of the Federation no longer possessed huge reserves that would enable them to promptly respond to falls; in addition, the Russian economy was to a large extent denied access to financing by foreign loans and investments (Menkiszak, Fischer, 2014). The sanctions imposed on Russia by the European Union and the United States following Russia's involvement in the conflict in eastern Ukraine, and the counter-measures 
implemented by Russia, seriously affected the inflow of foreign investment and consequently the entire Russian economy in 2014-2017. Structural reforms, the emergence of a more dynamic private sector, a reduced role of the state in economic processes and changes in taxation of the oil sector exercised a favorable influence on the Russian economy in 2018-2019.

The global financial and economic crisis led to a deep recession in the EU-27 in 2009, followed by a recovery in 2010. The real GDP growth rate in the EU was considerably diversified, both in time and between the member states. Following the economic recession that in 2009 affected all member states of the EU except Poland, 2010 saw a repeated economic growth trend in 23 member states and the situation continued in those 23 member states also in 2011. However, the trend was reversed in 2012 when only slightly more than half (14) of the member states reported economic growth, while the remaining member states saw a reduction in production. Eventually, a substantial majority of the member states recorded growth again. The group included 16 states in 2013, 23 states in 2014 and 26 states in 2015 and 2016. All 27 member states of the EU reported growth in 2017 for the first time since 2007. The trend continued in 2018 and 2019. The sole member state to record a drop in 2015 and 2016 was Greece (by $0.4 \%$ and $0.2 \%$ respectively), following a slight growth by $0.7 \%$ in 2014 and five successive reductions in economic output during the years 2009-2013 (Statistics Explained, 2020: 2).

In early 2020, the global economy, including the economies of Ukraine, the Russian Federation and the European Union, were exposed to a new and completely unforeseeable biological hazard that led to a severe downturn in economic growth and undermined the institutionally weak economic systems of Eastern European states. The enforced lockdown adversely affected the efficiency and effectiveness of social and economic systems (Zhalilo, Bazylyuk, Kovalivs'ka \& Kolomiyets', 2020).

Figure 4.2 (a, b, c) presents quarter-to-quarter changes in Gross Domestic Product in Russia, Ukraine and in European Countries. The lockdown measures implemented in Ukraine in the spring of 2020 continued for almost two months; the government introduced a "weekend quarantine" in the autumn, meaning almost complete lockdown on public holidays. On the basis of figures 4.2 (a) we can state that GDP per capita in Q2 of 2020 dropped by $8 \%$ compared to Q2 of 2019. Another lockdown was imposed in January 2021 for almost three weeks. An assessment of the effects of those measures on the economy is ambiguous. The Ukrainian ministry of economy announced that inflation in 2020 reached $5 \%$, principally due to a dynamic increase in revenues from retail sales and a rise in prices for energy sources on the global market that affected local expenses on public utility services, finally reducing the consumer demand.

The volume of cargo transport dropped in 2020 by $15 \%$ compared to the same period of 2019 while the passenger transport sector reached in 2020 only $46 \%$ of its revenues in the same period of 2019 . 


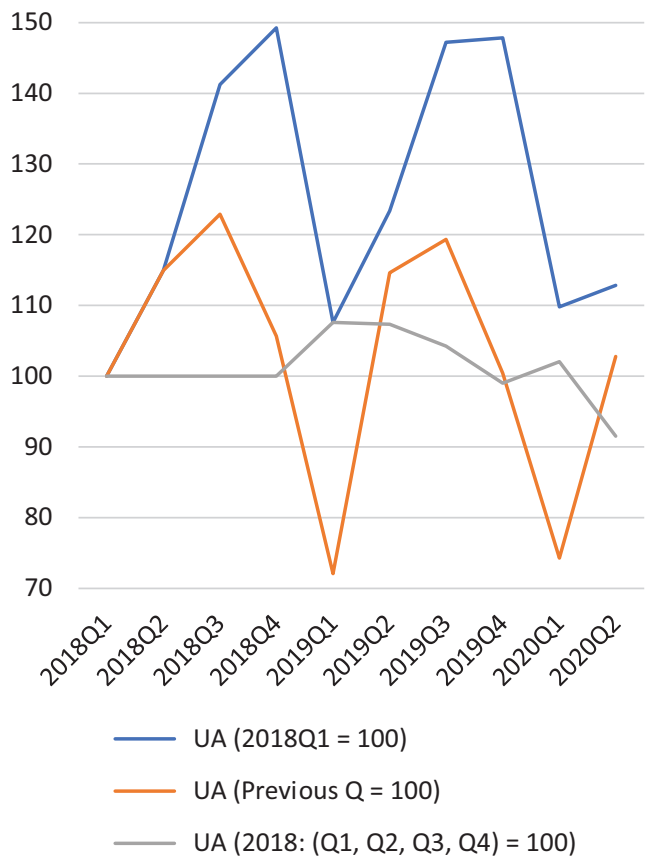

Figure 4.2a Changes in Gross Domestic Product per capita, at PPP, quarter-overquarter (2019-2020) in (a) Ukraine. Source: own calculation based on http://www.ukrstat.gov.ua/;https://eng.rosstat.gov.ru; https://ec.europa. eu/eurostat/data/database (accessed: 2021-01-30).

Russia faced an extremely high mortality rate caused by the COVID-19 pandemic in 2020; the Russian population decreased by almost 700,000 people. It was the deepest annual decrease of the last 15 years. Non-residents invested three times less in the business enterprise sector in H1 of 2020 than in the same period of 2019.

The result was five times less in the entire year 2020 than in 2019. Hence, the 2020+ pandemic seems to be only one of the factors causing problems in the Russian economy. Low oil prices, structural problems (labor market, a shallow financial market) and geopolitical risk affect the current situation and will have a decisive effect on the condition of the Russian economy in the future.

Maps 4.1(a) and 4.1(b) represent spatial differentiation of GDP per capita subsequently in Q2 of 2019 and Q2 of 2020 in the EU economies, the Russian Federation and Ukraine. A detailed description of changes in the member states of the European Union is contained in Chapter 2, hence we focus here on the differences in changes that take place between the EU economies and the Russian Federation and Ukraine. 

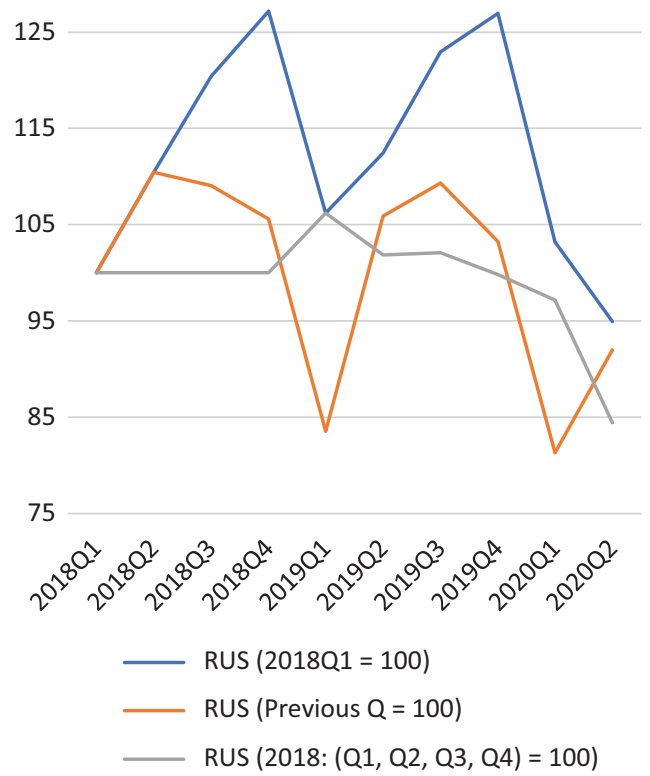

Figure 4.2b Changes in Gross Domestic Product per capita, at PPP, quarter-overquarter (2019-2020) in (b) Russia. Source: own calculation based on http://www.ukrstat.gov.ua/;https://eng.rosstat.gov.ru; https://ec.europa. eu/eurostat/data/database (accessed: 2021-01-30).

The analyzed economies were divided into quintile groups characterized by the lowest (five), low (six), average (five), high (six) and the highest (five) values; Slovakia was classified in an additional group due to the absence of available statistics. Both in Q2 of 2019 and in Q2 of 2020, Ukraine recorded the lowest values of the analyzed variable among all countries - this confirmed its status as the poorest state in the group covered by our analysis. The difference between Ukraine and the state with the lowest values of GDP per capita in Europe, i.e. Bulgaria, amounted in Q2 of 2019 to USD 291.83 while that difference fell to USD 31.61 in the same period of the following year. This indicates that the fall in economic output flow was deeper in Bulgaria than in Ukraine. However, the value of GDP per capita fell in Ukraine by USD 272.27 between the analyzed quarters; it was the lowest value of decrease among all the countries. The Russian Federation retained its rank between Q2 of 2019 and Q2 of 2020 and remained in the group characterized by low values of GDP per capita. 
105

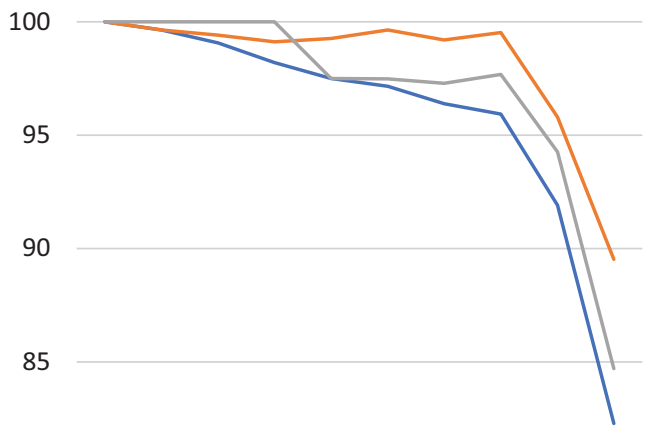

80

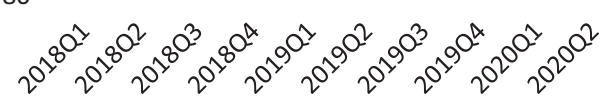

$-\operatorname{EU}(2018 \mathrm{Q} 1=100)$

EU (Previous $Q=100)$

— EU (2018: (Q1, Q2, Q3, Q4) = 100)

Figure 4.2c Changes in Gross Domestic Product per capita, at PPP, quarter-overquarter (2019-2020) in (c) the European Union. Source: own calculation based on http://www.ukrstat.gov.ua/; https://eng.rosstat.gov.ru; https:// ec.europa.eu/eurostat/data/database (accessed: 2021-01-30).

\subsection{Spatial interactions taking place on labor and product markets between the European Union, Russian Federation and Ukraine}

To identify the determinants of differences in labor productivity, we assume as our starting point the neoclassical Cobb-Douglas power production function (Cobb-Douglas, 1928):

$$
Y=f(K, L)=A e^{g t} K^{\alpha} L^{1-\alpha}
$$

where:

$Y$ - production,

$K$ - capital input,

$L$ - labor input,

$g$ - Hicks technical progress rate,

$A$ - total productivity of capital and labor input,

$\alpha$ and $\alpha-1-$ output elasticity $Y$ of capital $K$ and labor $L$ respectively (see Tokarski, 2008). 

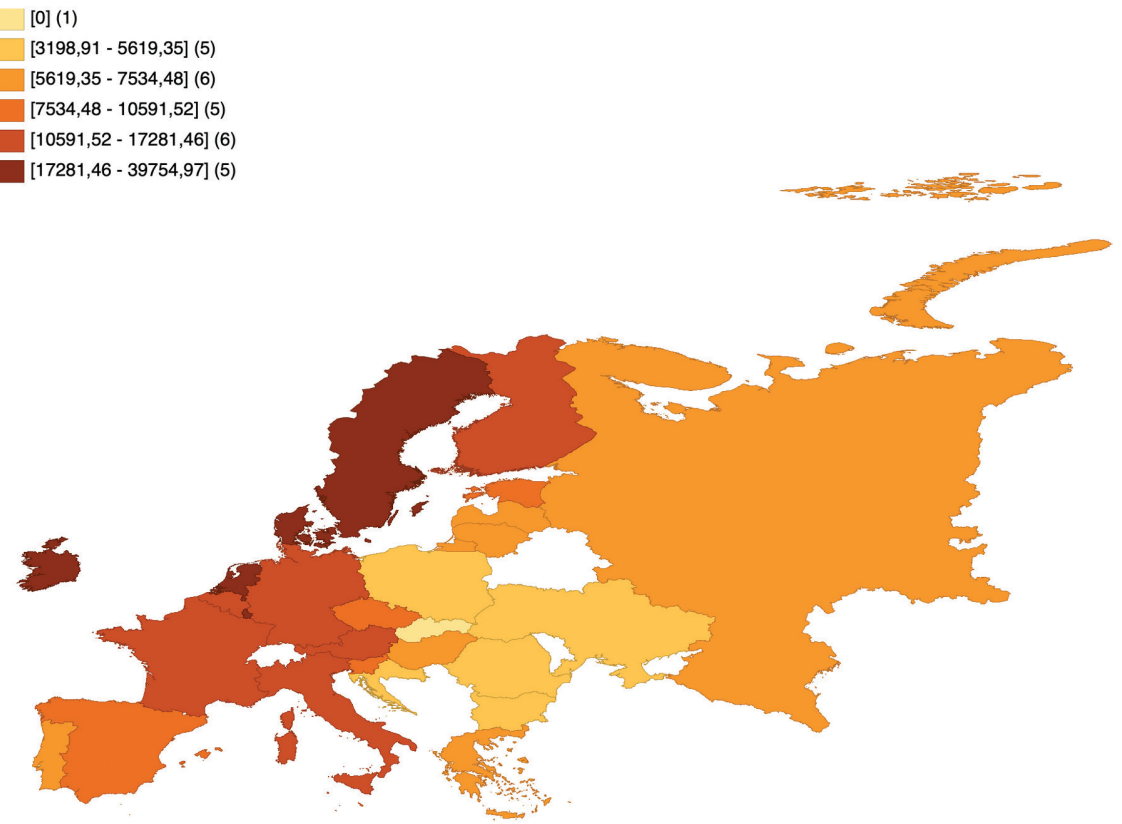

Map 4.1a Spatial differentiation of GDP per capita in Q2 of 2019 in the member states of the European Union, the Russian Federation and Ukraine (in USD, fixed prices from Q2 of 2020) Source: own calculations. based on https://ec.europa.eu/eurostat/data/database, http://www.ukrstat.gov.ua and https://rosstat.gov.ru.

After $\log$ transformation of both sides, we obtain the equation:

$$
\ln (Y)=\ln (A)+g t+\alpha \ln (K)+(1-\alpha) \ln (L)
$$

that facilitates transition from a power to a quasi-linear relation. Then the natural logarithm of the number of the employed is subtracted on both sides of equation (4.2) to obtain equation (4.3) that defines the natural logarithm of labor productivity.

$$
\ln \left(\frac{Y}{L}\right)=\ln (A)+g t+\alpha \ln \left(\frac{K}{L}\right)
$$

Equation (4.3) shows that labor productivity is determined by the technical progress rate, total productivity of inputs and capital-labor ratio. Based on equation (4.3), the parameters of equation (4.4) were estimated using data about the European Union, Russian Federation and Ukraine:

$$
\ln \left(\frac{Y_{i t}}{L_{i t}}\right)=\alpha_{0}+\alpha_{1} t+\alpha_{2} \ln \left(\frac{K_{i t}}{L_{i t}}\right)
$$



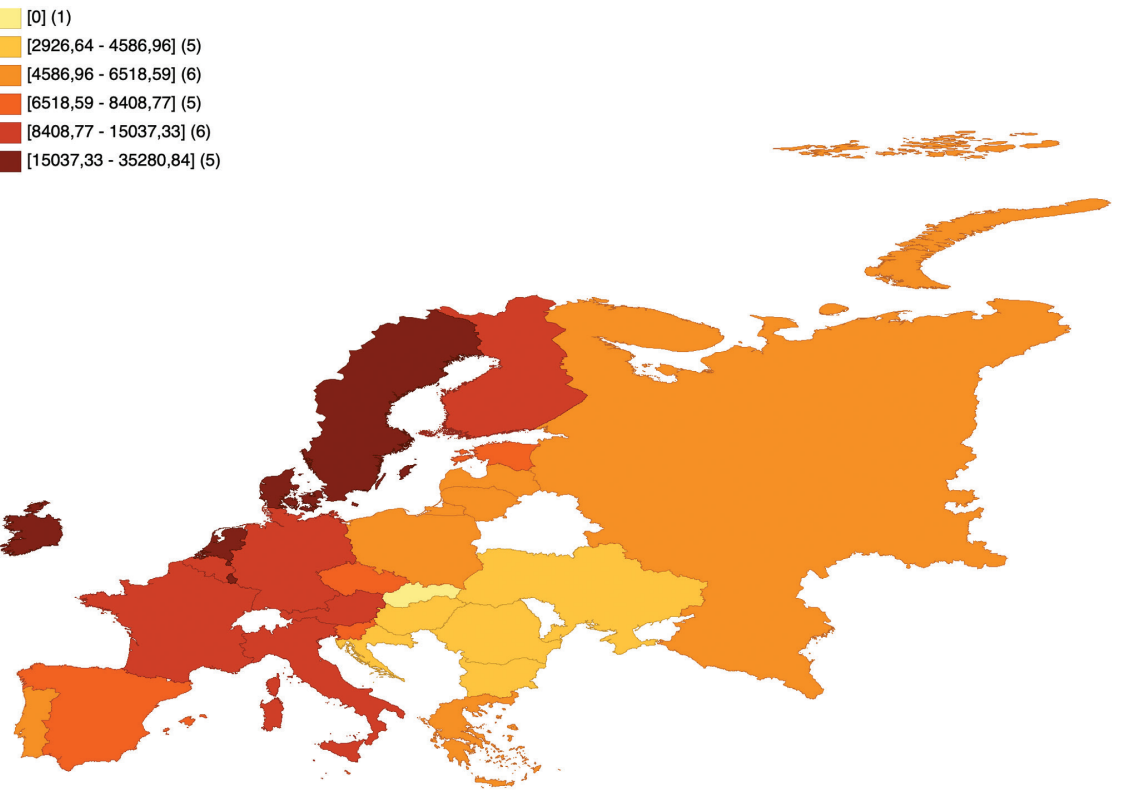

Map 4.1b Spatial differentiation of GDP per capita in Q2 of 2020 in the member states of the European Union, the Russian Federation and Ukraine (in USD, fixed prices from Q2 of 2020) Source: own calculations. based on https://ec.europa.eu/eurostat/data/database, http://www.ukrstat.gov.ua and https://rosstat.gov.ru.

where:

$Y_{i t}-$ GDP in object $i(i=1,2,3)$ in the year $t(t=1996,1997 \ldots, 2019)$,

$L_{i t}$ - number of the employed in object $i$ in the year $t$,

$K_{i t}-$ gross value of property, plant, equipment in enterprises in object $i$ in the year $t$,

$\alpha_{0}-$ the logarithm of total productivity of inputs,

$\alpha_{1}$ - a parameter that defines the effect of technical progress rate on labor productivity,

$\alpha_{2}$ - elasticity of labor productivity relative to the capital-labor ratio.

A definition of the unemployment rate is now used to statistically analyze an increase in unemployment rates. Based on a definition of the unemployment rate, its increase can be made conditional on the unemployment rate in the preceding period and the output growth rate. We adopt the following definition for this purpose (Tokarski, 2005):

$$
u(t)=\frac{U(t)}{U(t)+L(t)}=1-\frac{L(t)}{N(t)}
$$

where:

$u(t)$ - unemployment rate, 
$U(t)$ - number of the unemployed,

$L(t)$ - number of the employed,

$N(t)$ - labor supply.

By differentiating equation (4.5) in time $t$, we obtain an increase in the unemployment rate expressed by the derivative:

$$
\dot{u}(t)=-\frac{\dot{L}(t) N(t)-L(t) \dot{N}(t)}{N^{2}(t)}=\frac{L(t)}{N(t)}\left[\frac{\dot{N}(t)}{N(t)}-\frac{\dot{L}(t)}{L(t)}\right]
$$

The above relation and equation (4.5) indicate that an increase in the unemployment rate can be transformed into:

$$
\dot{u}(t)=(1-u(t))\left(\frac{\dot{N}(t)}{N(t)}-\frac{\dot{L}(t)}{L(t)}\right)
$$

An analysis of equation (4.6) leads to the conclusion that the rate of growth in the number of the employed $\frac{\dot{L}(t)}{L(t)}$ is an increasing function of the output growth rate $(g)$. Hence, there is a mapping $(f)$ so that $\frac{\dot{L}(t)}{L(t)}=f(g)$ and $\frac{d f}{d g}>0$; then, an increase in the unemployment rate is described using the following formula:

$$
\dot{u}(t)=(1-u(t))\left[\frac{\dot{N}(t)}{N(t)}-f(g)\right]
$$

An analysis of relation (4.7) leads to the conclusion that an increase in the unemployment rate is determined by the output growth rate $(g)$, labor supply growth rate $\left(\frac{\dot{N}(t)}{N(t)}\right)$ and unemployment rate $(\underline{u}(t))$. Additionally, an increase in the unemployment rate is a decreasing function of the output growth rate $(g)$, and an increasing function of the labor supply growth rate $\left(\frac{\dot{N}(t)}{N(t)}\right)$. If the labor supply growth rate is greater (less) than the employed number growth rate, a rise in the unemployment rate is a decreasing (an increasing) function of the unemployment rate.

Based on the above theoretical discussion of the factors determining increases in unemployment rates (equation 4.7), the parameters of the following equation are estimated: ${ }^{1}$

$$
\Delta u_{i t}=\alpha_{0}-\alpha_{1} u_{i t-1}+\alpha_{2} d_{\Delta u} u_{i t-1}-\alpha_{3} \Delta \ln \left(Y_{i t}\right)
$$

1 Equation (4.8) ignores the labor supply growth rate because fluctuations in labor supply were relatively insignificant compared to changes in unemployment in the years 1996-2019. 
where:

$$
u_{i t}=\frac{U_{i t}}{U_{i t}+L_{i t}}-\text { registered unemployment rate in economy } i(i=1,2,3) \text { in }
$$

the year $t(t=1996,1997 \ldots, 2019)$;

$\Delta \operatorname{In}\left(Y_{i t}\right)$ - labor productivity growth rate in object $i$ in the year $t$,

$\alpha_{0}-$ a constant defining an increase in the unemployment rate that would be observed at a zero unemployment rate in the preceding period and zero labor productivity rate,

$\alpha_{1}$ a variable defining the strength of effect exerted by the unemployment rate from the preceding period on the increase in the unemployment rate where that variable does not grow,

$\alpha_{2}-$ a measure of the strength of effect exerted by the unemployment rate from the preceding period on the increase of that variable where the rate grows,

$\alpha_{3}$ - describes the relation between the increase in the unemployment rate and the labor productivity growth rate,

$d_{\Delta u}$ - a dummy variable that takes on the value of 1 if the unemployment rate grows, and otherwise equals 0 .

An interpretation of the parameters $\alpha_{1}$ and $\alpha_{2}$ is dictated by a dichotomous variable $d_{\Delta u}$. This is because that variable, in the equation describing an increase in unemployment rates, plays the role of a switching variable that adjusts the effect of the unemployment rate from the preceding period on a change in the current unemployment rate by including its growth or drop.

The seemingly unrelated regression (SUR) method as developed by Zellner (Zellner, 1962) was used in estimations of equations (4.4) and (4.8); the parameters of all equations were estimated simultaneously so that the parameters of each equation incorporate information about the other equations. This method leads to an improved efficiency of parameters estimated, by using additional information. With an increase in correlation between error vectors of the analyzed equations, in the number of observations and with a greater linear relationship between explanatory variables the efficiency of estimated parameters grows (Yahya et al., 2008). The SUR method is used to simultaneously estimate the parameters of all analyzed equations, considering correlations between them.

In equation (4.4), the logarithm of labor productivity is adopted as an endogenous variable in the models while the logarithm of capital-labor ratio and the technical progress growth rate represent exogenous variables. In equation (4.8), independent variables such as the unemployment rate from the preceding year and the logarithm of labor productivity explain an increase in the unemployment rate. The analysis covers the longest period for which sufficient data can be obtained: the years 1996-2019. Cash variables are converted into fixed prices from 2010. Statistical significance is indicated next to values using the following markings: confidence level < 0.01 as $* *$, confidence level $<0.05$ as $* *$ and confidence level $<0.1$ as $*$; 
also estimation errors are given in brackets. The tables also contain the coefficient of determination $R^{2}$, here understood as a percentage of variance of the dependent variable explained by variability of the dependent variables, and included for purely descriptive purposes, not as a coefficient of determination used in traditional econometrics.

Estimations of equations (4.4) and (4.8) using the SUR method are accompanied by a table of results containing the values of correlation coefficient of random components $e_{i t}$. The correlation coefficient of random components is calculated for each pair of equations that are subsequently represented in a matrix of correlations of random variables. Additionally, the value of the statistic obtained in the Breusch-Pagan ${ }^{2}$ test is given below the matrix to show whether there are correlations between random interferences in individual equations.

Tables 4.1 and 4.2 contain results of estimations of the parameters of equations (4.4) and (4.8). The estimates of structural parameters of regression equations that describe labor productivity in the analyzed economies proved to be statistically significant. The elasticity of labor productivity relative to the capital-labor ratio in the European Union and in Ukraine were similar while in the Russian Federation it was clearly higher. However, the estimated parameters defining technical progress rates are significantly different: in the European Union, the value of that rate is three times lower than in Ukraine and almost two times lower than in the Russian Federation.

Table 4.1 Estimates of the parameters of equation (4.4) for the European Union, Russian Federation and Ukraine

\begin{tabular}{llll}
\hline Regressors & European Union & Russian Federation & Ukraine \\
\hline $\ln \left(\frac{K_{i t}}{Y_{i t}}\right)$ & $0.3960 * * *$ & $0.4251 * * *$ & $0.3861 * * *$ \\
$g$ & $(0.0204)$ & $(0.0210)$ & $(0.0437)$ \\
& $0.0066 * *$ & $0.0111 * * *$ & $0.0198 * * *$ \\
constant & $(0.0027)$ & $(0.0013)$ & $(0.0022)$ \\
number of observations & 24 & $-15.7639 * * *$ & $-33.9315 * *$ \\
$R^{2}$ & $-5.8624 * * 045)$ & $(2.3839)$ & $(4.3949)$ \\
RMSE & 0.9899 & 24 & 24 \\
European Union & 0.0073 & 0.9938 & 0.9089 \\
Russian Federation & 1.0000 & 0.0191 & 0.0701 \\
Ukraine & 0.3821 & 1.0000 & \\
Breusch-Pagan test & 0.4948 & -0.1795 & 1.0000 \\
\hline
\end{tabular}

Source: own calculation based on http://www.ukrstat.gov.ua/; https://eng.rosstat.gov.ru; https://ec.europa.eu/eurostat/data/database (accessed: 2021-01-30).

2 The test statistic is based on chi-squared distribution. The number of degrees of freedom in the test is given in brackets and equals $\frac{M(M-1)}{2}$, where $M$ represents the number of equations in the model, estimated using the SURE method. 
82 Olesia Chornenka et al.

Table 4.2 Estimates of the parameters of equation (4.8) for the European Union, Russian Federation and Ukraine

\begin{tabular}{llll}
\hline Regressors & European Union & Russian Federation & Ukraine \\
\hline$u_{i t-1}$ & $-0.0013 *$ & $0.2741 * *$ & $-0.1539 *$ \\
$d \Delta u_{i t-1}$ & $(0.0012)$ & $(0.1442)$ & $(0.1055)$ \\
$\Delta \operatorname{In} Y_{i t}$ & $0.0110 * *$ & $0.0143 * * *$ & $0.0148 * *$ \\
& $(0.1381)$ & $(0.0029)$ & $(0.0026)$ \\
constant & $-0.0093 *$ & $0.0163 * *$ & $-0.0138 * *$ \\
& $(0.0203)$ & $(0.0086) * * 1597 *$ & $(0.0053)$ \\
number of observations & $0.0833 *$ & $-0.159)$ & $0.1055 * *$ \\
$R^{2}$ & $(0.2062)$ & $(0.0800)$ & $(0.0441)$ \\
RMSE & 24 & 24 & 24 \\
European Union & 0.6490 & 0.6101 & 0.7105 \\
Russian Federation & 0.0041 & 0.0064 & 0.0059 \\
Ukraine & 1.0000 & & \\
Breusch-Pagan test & 0.0727 & 1.0000 & 1.0000 \\
\hline
\end{tabular}

Source: own calculation based on http://www.ukrstat.gov.ua/; https://eng.rosstat.gov.ru; https://ec.europa.eu/eurostat/data/database (accessed: 2021-01-30).

The coefficient of correlation between the random components of the equations describing labor productivity in the European Union and Russian Federation and the European Union and Ukraine is positive. Only the equation for the Russian Federation and Ukraine responds otherwise to random interferences. The value $p$ of the Breusch-Pagan test statistic clearly demonstrates that the relations between random components of equation pairs are statistically significant. Additionally, the estimated equations of the SUR model convincingly explain the variability of labor productivity in the discussed economies.

The estimates of structural parameters of the equations describing increases in unemployment rates in the SUR model for the European Union, Russian Federation and Ukraine are statistically significant but their signs are not always consistent with economic theory. The estimates of parameters for the Russian Federation seem to be inconsistent with economic theory (an exception is provided by the parameter defining the effect of unemployment from the preceding period under conditions of increase in that variable). Additionally, fluctuations in the unemployment rate in prior periods had a much stronger effect on the current increase in that variable in Ukraine than in the European Union. A similar, although slightly weaker relation, is observed in the value of elasticity of increase in current unemployment relative to labor productivity; the response of unemployment rates to changes in the labor productivity growth rate is about $50 \%$ weaker in the European Union.

The goodness of fit of the equations to empirical data, as measured by a quasi-coefficient " $\mathrm{R}$ ", is lower than in the case of the equation describing 
labor productivity; it can also be concluded that the SUR model quite satisfactorily explains variability in the increase in the unemployment rate. However, the result of the Breusch-Pagan test did not confirm that there are statistically significant spatial interrelations between the European Union, Russian Federation and Ukraine.

Correlations between simultaneous random components are weak, and it can be concluded that objects constituting the aggregate are generally independent. That independence is understood as varying responses (meaning directions of development) of an increase in the unemployment rate to external factors. The result of Breusch-Pagan test did not confirm that there are statistically significant spatial interrelations between the European Union, Russian Federation and Ukraine. Correlations between simultaneous random components are weak, and it can be concluded that objects constituting the aggregate are generally independent. That independence is understood as varying responses (meaning directions of development) of an increase in the unemployment rate to external factors.

\subsection{Fiscal interventions in Ukraine and Russia in 2020}

The COVID-19 pandemic posed a considerable challenge to the global economy, principally because it did not represent a "classical" economic crisis or a local epidemic crisis (Zhalilo, Bazylyuk, Kovalivs'ka and Kolomiyets', 2020). Governments had to choose between protecting societies against the virus and maintaining the existing level of welfare. The principal method used to protect society was the implementation of lockdown measures with varying severity combined with public transfers, such as subsidies directed to selected economic sectors, co-financing of small and medium-sized businesses, reductions in (or partial exemption from) taxes, etc.

\subsubsection{Ukraine}

The decisions made by the Ukrainian government, aimed to limit the adverse impact of the COVID-19 pandemic on the Ukrainian economy, were not exceptional compared to measures taken in many other countries. Public aid included (KMU, 2020):

- loan moratoriums,

- tax allowances,

- $\quad$ support provided to small and medium-sized businesses,

- $\quad$ separate, dedicated support provided to agriculture,

- information assistance provided to businesses.

The Ukrainian central bank recommended that Ukrainian commercial banks offer borrowers debt restructuring plans (Decree no. 39 of 26 March 2020 
(Постанова НБУ №39 від 26 березня 2020 року)) (NBU, 2020a). The central bank proposed two principal versions of debt restructuring:

- complete or partial exemption from repayment of principal loan amount for the quarantine duration with an extension of financing term,

- capitalization of interest.

Additionally, a ban was imposed on rises in interest rates on loans between 1 March and 30 November 2020. Also, a ban on fines and penalties for delays in loan repayment was imposed in that period. A long-term bank refinancing mechanism was launched and the algorithm for recognition of required reserves was changed (Zhalilo, Bazylyuk, Kovalivs'ka \& Kolomiyets', 2020). The government adopted a series of fiscal measures:

- exemption from charges for land use for business purposes and from tax on real property (residential spaces) in March 2020,

- limitation of most fines imposed for tax offences,

- a moratorium on tax inspections (except inspection of refunded VAT),

- exemption from VAT of importers and suppliers of medications, medical devices, medical apparatus and other goods used to contain the spread of COVID-19 in the territory of Ukraine,

- increased annual income limits for groups 1,2 and 3 of entrepreneurs,

- zero rate of excise tax for state enterprises manufacturing alcohol-based disinfectants,

- power to set tax rates for small businesses delegated to local government (Сдиний податок) (KMU, 2020).

Support provided to small and medium-sized businesses included principally subsidies to employee pay. Act no. 3275 (Закон України “Про внесення змін до деяких законодавчих актів, спрямованих на забезпечення додаткових соиіальних та економічних гарантій у зв'язку з поширенням коронавірусної хвороби (COVID-2019)" (VRU, 2020)) introduced the concept of "partial unemployment" for the time of quarantine. The Act lays down the conditions for assistance provided to small and medium-sized enterprises in the form of benefits payable to partially unemployed personnel of those enterprises.

The agricultural sector is of key importance for the Ukrainian economy; almost $20 \%$ of the employed in Ukraine work in agriculture. The proportion of income from the agricultural sector in Ukrainian GDP is the largest in Europe (about 10\%) (Bosak \& Mustafaieva, 2019; SSSU, 2020). Ukraine allocated EUR 131 million to its farmer support programme. The government allocated an additional EUR 39 million to a reduction in debt of the agricultural sector. It is expected that the programme will contribute to the establishment of 100 new farms and agricultural-industrial complexes that will create 1,700 new jobs (KMU, 2020). 
To assist entrepreneurs in their business activity during the quarantine, the government created several information platforms, providing data and enabling people to register a business and obtain online tax advice.

Due to a series of tax allowances granted, tax income of public sector institutions significantly dropped, e.g. receipts from social insurance premiums decreased (Сдиний соціальний внесок). An estimated reduction in tax receipts due to exemptions from payment of insurance premiums amounts to EUR 66 monthly (Zhalilo, Bazylyuk, Kovalivs'ka \& Kolomiyets', 2020). Consequently, the budget deficit in 2020 was the largest in the 20 years of independent Ukraine. The budget deficit was compensated using new sovereign loans which translated into an increase in public debt as of the end of 2020 (Kulyts'kyy, 2020a).

\subsubsection{Russia}

The principal state intervention measures implemented in Russia in 2020 can be divided into general, social and economic. The set of general measures includes:

- restrictions imposed on spatial mobility of people (including administrative and criminal liability for failure to meet those conditions),

- various simplified regulations adopted to maintain continuity of social and economic functions, such as licences for the manufacture and sales of alcoholic drinks, provision of telecommunication services, detective and security guard activity extended until the end of 2020, simplified doctoral examinations, extended deadlines for payment of patent fees, etc.

Principal methods employed to support continued social functions include:

- medications and medical devices, including personal protective equipment, and materials for their manufacture and disinfectants used to contain the spread of coronavirus in the territory of Russia are exempted from customs duties,

- simplified registration procedure of medications and medical devices,

- exemption from VAT of imported medical goods transferred to healthcare centers treating patients with the coronavirus,

- simplified application for and granting of social benefits; parents of children aged below 16 and people who lost their jobs during the pandemic, and employees of the healthcare sector received additional support during the quarantine.

Tax holidays were granted in the sectors adversely affected by the COVID19 pandemic, like in Ukraine:

- social insurance premiums payable by small and medium-sized enterprises were reduced, 
- a moratorium on state (including customs and tax) inspections was declared,

- entrepreneurs from selected sectors were exempted from certain taxes, enterprises of key importance for the Russian economy were granted the option to defer payment of their tax liabilities,

- electricity producers, banks, and car manufacturers obtained subsidies amounting to EUR 281 million in total, and airports received about EUR 122 million,

- interest rates on loans taken out by enterprises adversely affected by the pandemic were reduced, or interest on loans was cancelled to enable enterprises to give pays,

- a simplified procedure for agricultural enterprises requesting low-interest loans; a loan moratorium for small and medium-sized enterprises in the form of loan fees deferred for 6 months (RFG, 2020).

Russian state interventions affected the condition of the public finance sector, like in Ukraine. Adverse trends were also recorded in the Russian balance of payments, due to a reduced volume of exports from the energy sector (World Bank, 2020).

\subsection{Conclusions}

Russia possessed in 2008-2010 considerable foreign currency reserves, amassed in the years 2000-2008 due to high and rising prices for raw materials. Despite unfavorable macroeconomic and microeconomic indicators, Russians' real income continued to grow in that period, due to considerable funds from foreign exchange reserves redirected to the domestic market. The sanctions imposed on Russia by the European Union and the United States following Russia's involvement in the conflict in eastern Ukraine, and the counter-measures implemented by Russia, seriously affected the inflow of foreign investment and consequently the entire Russian economy in 2014-2017.

The Ukrainian economy was exposed to three major demand and supply shocks in 2008-2020 that increased institutional, economic and social instability in Ukraine. Generally, the $2020+$ pandemic increased instability of the institutional and economic systems in Ukraine and Russia.

The global financial and economic crisis led to a deep recession in the EU-27 in 2009, followed by a recovery in 2010. Only 14 member states recorded economic growth in 2012, the remaining reported a decrease in production. All 27 member states of the EU recognized economic growth in 2017 for the first time since 2007.

In early 2020, the global economy, including the economies of Ukraine, Russia and the European Union, were exposed to a new and completely unforeseeable biological hazard that led to a severe downturn in economic growth. The Ukrainian ministry of economy announced that inflation in 
2020 reached $5 \%$, principally due to a dynamic increase in revenues from retail sales and a rise in prices for energy sources on the global market that affected local expenses on public utility services, finally reducing the consumer demand. The passenger transport sector achieved in 2020 only $46 \%$ of its revenues earned in the same period of 2019. Russia faced an extremely high mortality rate caused by the COVID-19 pandemic in 2020; the Russian population decreased by almost 700,000 people. It was the deepest annual decrease of the last 15 years. Non-residents invested in the business enterprise sector in 20205 times less capital than in 2019. The 2020+ pandemic seems to be only one of the factors causing problems in the Russian economy.

Estimates of the structural parameters of equations describing increases in unemployment rates in the SURE model for the European Union, Russian Federation and Ukraine lead to ambiguous results. Generally, fluctuations in the unemployment rate in prior periods had a much stronger effect on the current increase in that variable in Ukraine than in the European Union. A similar, although slightly weaker relation, is observed in the value of elasticity of increase in current unemployment relative to labor productivity; the response of unemployment rates to changes in the labor productivity growth rate is about $50 \%$ weaker in the European Union (exogenous shocks in 2008-2020).

\section{References}

Bosak, A., Mustafaieva, L. (2019). Current status and prospects for agricultural development: Search of new markets of acquisition, Naukovyy visnyk UzhNU. Seriya: Mizhnarodni ekonomichni vidnosyny ta svitove hospodarstvo, 24, 48-54.

Cobb C. W., Douglas P. H. (1928). A theory of production. American Economic Review, 18, 139-165.

Drobot, Y., Makarov, I., Nazarenko, V., Manasyan, S. (2020). Vliyaniye pandemii COVID-19 na real'nyy sektor ekonomiki. Ekonomika, predprinimatel'stvo $i$ prawo, 8, 2135-2150.

KMU (2020). Prohramy pidtrymky biznesu. https:/COVID19.gov.ua/prohramypidtrymky-biznesu (accessed January 30, 2021).

Kulyts'kyy, S. (2020a). Problemy rozvytku ekonomiky Ukrayiny, obumovleni pandemiyeyu koronavirusu COVID-19 u sviti, ta poshuk shlyakhiv yikh rozv'yazannya. Ukrayina: podiyi, fakty, komentari, 9, 47-53.

Kulyts'kyy, S. (2020b). Ukrayins'kyy rynok pratsi pid vplyvom pandemiyi COVID19: Stan ta otsinka perspektyv rozvytku. Ukrayina: podiyi, fakty, komentari, 12, 43-57.

Łobuszewska, A. (ed.), Kazimierska, K., Mańkowski, W. (2015). Kryzys gospodarczo-finansowy w Rosji. Uwarunkowania, przejawy, perspektywy. Ośrodek Studiów Wschodnich, Warszawa.

Menkiszak, M., Fischer E. (2014, 17 December). Kryzys putinowskiego modelu gospodarki w Rosji, osw.waw.pl, http://www.osw.waw.pl/pl/publikacje/analizy /2014-12-17/kryzys-putinowskiego-modelu-gospodarki-w-rosji (accessed January 30, 2021). 


\section{Olesia Chornenka et al.}

NBU (2020a). Inflyatsiynyy zvit. Zhovten' 2020 roku. https://bank.gov.ua/admin _uploads/article/IR_2020_Q4.pdf?v=4 (accessed January 30, 2021)

NBU (2020b). Postanova № 39. https://bank.gov.ua/ua/legislation/Resolution 26032020_39 (accessed January 30, 2021).

RFG (2020). Plan preodoleniya ekonomicheskikh posledstviy novoy koronavirusnoy infektsii. http://static.government.ru/media/COVID19/plans/9Wdz2EDiAKsn7rj QWFkg5eRvHYLtDhee/PlanRF.pdf (accessed January 30, 2021).

SSSU (2020). Agriculture of Ukraine. http://www.ukrstat.gov.ua/druk/publicat/kat _u/2020/zb/09/zb_sg_Ukr_2019.pdf (accessed January 30, 2021).

Statistics Explained (2020, 30 November). National accounts and GDP. https://ec .europa.eu/eurostat/statisticsexplained/ (accessed January 30, 2021).

Tokarski, T. (2005). Statystyczna analiza regionalnego zróżnicowania wydajności pracy, zatrudnienia i bezrobocia $w$ Polsce. Wydawnictwo PTE, Warszawa.

Tokarski, T. (2008). Oszacowanie regionalnych funkcji produkcji. Wiadomości Statystyczne, 10, 38-53.

VRU (2020). Zakon Ukrainy "Pro vnesennya zmin do deyakykh zakonodavchykh aktiv Ukrayiny, spryamovanykh na zabezpechennya dodatkovykh sotsial'nykh ta ekonomichnykh harantiy u zv"yazku z poshyrennyam koronavirusnoyi khvoroby (COVID-19)". https://zakon.rada.gov.ua/laws/show/540-20?lang=en\#Text (accessed January 30, 2021).

World Bank (2020). Russia economic report, no. 43, July 2020: Recession and growth under the shadow of a pandemic. World Bank, Washington, DC. https:// openknowledge.worldbank.org/handle/10986/34219License:CCBY3.0IGO (accessed January 30, 2021).

World Bank (2021). International Comparison Program, World Bank. World Development Indicators database, World Bank. Eurostat-OECD PPP. https:// data.worldbank.org/indicator/NY.GDP.PCAP.PP.KD?locations=UA-RU\&view= chart (accessed June 30, 2021).

Yahya, W. B., Adebayo, S. B., Jolayemi, E. T., Oyejola, B. A., Sanni, O. O. M. (2008). Effects of non-orthogonality on the efficiency of seemingly unrelated regression (SUR) models. InterStat Journal, 1, 1-29.

Zellner, A. (1962). An efficient method of estimating seemingly unrelated regressions and tests for aggregation bias. Journal of the American Statistical Association, 57, 348-368.

Zhalilo, Y., Bazylyuk, Y., Kovalivs'ka, S., Kolomiyets', O. (2020). Ukrayina pislya koronakryzy-shlyakh oduzhannya. Natsilnal'nyy Instytut Stratehichnykh Doslidzhen', 304. 